\title{
How Confident are EFL Prospective Teachers toward Technology?
}

Fika Megawati ${ }^{*}$

Fitria Nur Hasanah ${ }^{2}$

Choirun Nisak Aulina ${ }^{3}$

Mauliya Avivi ${ }^{4}$

Nur Sholikha Muntiari ${ }^{5}$

${ }^{1}$ Universitas Muhammadiyah Sidoarjo,

Sidoarjo, Indonesia

”fikamegawati@umsida.ac.id

Article History: Submitted on $27^{\text {th }}$ May 2020; Accepted on $13^{\text {th }}$ August 2020; Published on $31^{\text {th }}$ December 2020

\begin{abstract}
The advance of ICT development in educational context encourages educators to increase their competence towards technology integration for classroom activities. Consequently, this phenomenon affects teacher education program to equip student teachers as the digital natives in this fourth industrial revolution era with skills accommodating their technology literacy as well as practice. Before deciding the activities as well as the supplementary sources for ICT based courses, technology confidence is an important step for an institution's initial development. This study aims to investigate technology competence of English prospective teachers in terms of applications use capability, technology confidence based on GPA, and TPACK confidence. Questionnaire was used as the instrument, and it was administered to twenty eight participants. The data was analyzed descriptively. The findings reveal that most of the subjects are familiar with the technology application. Further, not all of the subjects are confident to their ICT competence. Inserting GPA information to the prospective teachers' profile, it shows that high GPA do not guarantee high confidence in ICT use. Dealing with TPACK, the confidence result indicates that more than $45 \%$ participants integrate technology in their English classroom. This study implies that attempts fostering the student teachers' TPACK confidence in the context of English Language Teaching are highly needed.
\end{abstract}

Keywords: technology integration, TPACK confidence, digital literacy 


\begin{abstract}
ABSTRAK
Semakin berkembangnya teknologi informasi dan komunikasi (TIK) di bidang pendidikan mendorong para pendidik untuk meningkatkan kompetensinya di bidang integrasi teknologi. Hal tersebut juga mempengarubi program pendidikan guru untuke. membekali para calon guru yang merupakan digital native dengan literasi teknologi yang memadai dan memberikan model integrasi yang efektif sehingga mampu mnegakomodir kebutuban belajar siswa di era revolusi industri 4.0. Namun demikian, untuk menentukan model integrasi dan program peningkatan kualitas dosen yang tepat, tahap awal yang penting dilakukan adalah analisa kepercayaan diri mahasiswa calon guru terhadap penggunaan teknologi. Penelitian ini bertujuan untuk. menginvestigasi kompetensi teknologi mahasiswa calon guru Bahasa Inggris dalam hal kemampuan penggunaan aplikasi teknologi, kepercayaan diri pada teknologi berdasarkan IPK, dan kepercayaan diri berdasarkan TPACK framework. Angket digunakan sebagai instrumen pada penelitian ini dan diberikan kepada 28 subjek, penelitian. Data yang diperoleh dianalisis secata deskriptif. Hasil penelitian ini menunjukkan bahwa sebagian besar mahasiswa calon guru Bahasa Inggris mengetahui berbagai macam aplikasi teknologi. Kemudian, tidak semua subjek merasa percaya diri pada kompetensi ICT mereka. Menggunakan IPK sebagai tambahan profil subjek, penelitian mengindikasikan bahwa IPK tinggi tidak. menjamin kepercayaan diri terbadap ICT juga tinggi. Pada TP ACK framework, hasil menunjukkan babwa lebih dari $45 \%$ mahasiswa calon guru merasa percaya diri untuke. mengintegrasikan teknologi pada pembelajaran di kelas.
\end{abstract}

Kata kunci: integrasei teknologi, kepercayaan diri terbadap TPACK, literasi digital

\title{
INTRODUCTION
}

Online application has attracted all elements of people's activities, including in educational context. Significantly, both teachers and students broaden their competence to be a smart user of technology. This phenomenon also affects teacher preparation program to equip teacher candidates with appropriate skills towards the technology integration in learning. This awareness is in line with today's teachers' candidates who are considered as digital natives in this $21^{\text {st }}$ century. They are capable enough to operate gadgets compared to the elder teachers. Focusing on English language learning, teacher candidates need to be trained to create joyful and meaningful learning by integrating relevant technology. Although they are literate to the digital devices, sometimes the skill is not applicable for classroom context. (Batane \& Ngwako, 2017). To define technology, teacher candidates seem to find challenges as well as barriers appearing during the technology use (Christ et al., 2019).

TPACK is one of frameworks promoted by Mishra \& Koehler (2006) used to analyze technology integration for teacher candidates. There are seven domains from three main aspects—content knowledge, pedagogical 
knowledge, and technological knowledge-which are closely related, and it helps both teachers and teacher candidates identify what to use, why to use, and how to use technology in learning activities. The teacher candidates probably get familiar with the three important aspects. However, limited teaching experience to explore technology use in the classroom seems to give a certain perception on how teacher candidates define and apply technology integration. Accordingly, it is important to investigate ICT competence in the last semester of study period including TPACK confidence. Further, limited empirical studies discussing score of Grade Average Point (GPA) attracted this study to discuss here.

The importance of technology integration skill for teachers can be seen in the statement of UNESCO (2011) that in teacher competence framework, there are six categories that need to be known and applied: (1) understanding ICT in education; (2) Curriculum and Assessment; (3) Pedagogy; (4) application of digital skill; (5) Organization and Administration; (6) Teacher Professional Learning. The framework is described in graphic 1.

Graphic 1:

Teachers' ICT Competence Framework based on UNESCO, 2019)

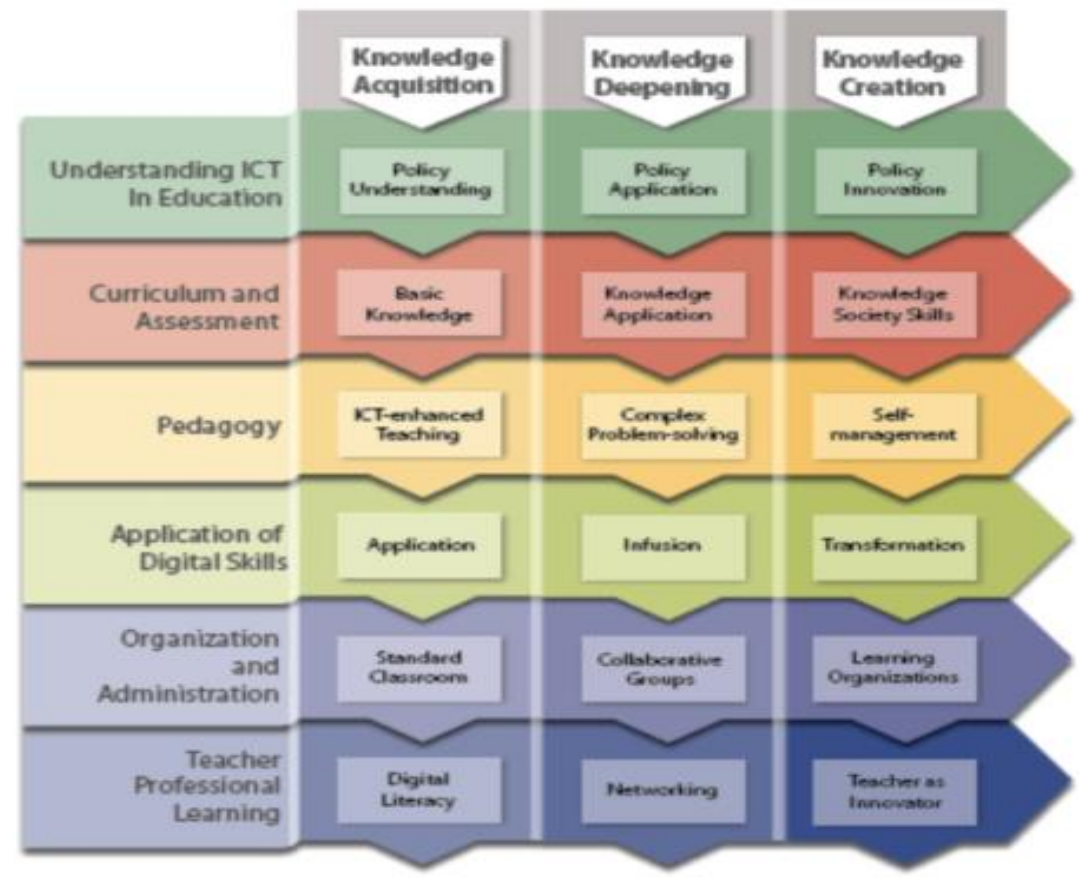

Based on the competence framework, it is stated that technology integration in educational context is not based on personal interest or trend, but it has been the demand of the world in order that every person prepare the global change optimally to face inclusive knowledge societies for sustainable development. 
TPACK Confidence Survey (TCS) is one of interesting topics to study. Wang et al. (2018) in their review state that TPACK in teacher candidates is an emerging issue for research. The development of each dimension in TPACK can be identified from several ways such as selfreport measures, open-ended questionnaires, performance assessments, interviews, and observations. However, from the existing instruments, it seems that there is a need to develop more accurate TPACK confidence. Therefore, Jamieson-Proctor, Romina Finger \& Albion (2010) tried to develop tool through constructing and validating instrument for TPACK confidence. As a result, the instrument is able to measure TPACK in large scale. Moreover, their study explored the relationship between TPACK confidence and the status of institution, age, gender, and study program across situational backgrounds (metropolitan and regional) in Queensland.

Further, a study by Al-Abdullatif (2019) mentions that prospective teachers in one of Saudi Arabia universities have high level of ICT confidence in the process of teaching and learning. In this context, TPACK refers to ICT competence, not completely investigate each domain the framework. The findings reveals that personally the prospective teachers show little interest towards ICT and the use of ICT is restricted to the activity in the classroom learning. Another similar study was carried out by Raman (2014). In his study, 154 prospective teachers majoring in three different departments-Technology and Information, moral education, and Accounting \& Management-were involved. The findings indicate that prospective teachers' competence, confidence, and TPACK are high. Additionally, in this study, gender contributes to the different skill towards ICT use.

Investigating the relationship of ICT and GPA have been studied previously. Lepp et al. (2015) provide evidence dealing with the effect of ICT use towards GPA. The result of the study shows that the frequent use of mobile phone gave impacts to the low academic performance of the students. Slightly different from previous study's result, Yunita et al. (2018) found that use of cell phone is not significantly distract to the students' GPA. In 2014, Lepp et al. (2014) explored the same topic but different findings. The use of mobile phone was not related to GPA and contributed to learners' anxiety. Regarding the possibility of exploring the relationship between technology and GPA, this study is interested to know whether GPA affects to EFL learners' ICT confidence.

Besides, considering limited studies focusing on English prospective teachers' TPACK confidence, this study is interested in this area for some rationales. First, English language learners have certain characteristics in their learning process, it is more meaningful for theoretical contribution if the study does not compare it with learners from other majors. In English class, four skills are exposed to the learners: listening, speaking, reading and writing. Besides, three language 
components support the development of each skill, which is, vocabulary, Grammar, and Pronunciation. Thus, the technology integrated needs to be specified based on expected learning outcomes, learners' condition, and the availability of IT facilities. To bridge the gap, the research questions are formulated as follow:

1. How are English teacher candidates' competence in using technology?

2. How confident are English teacher candidates in using technology across GPA?

3. How are English teacher candidates' TPACK confidence?

\section{METHOD}

This study used descriptive quantitative method with a survey design. To investigate ICT competence, the level of confidence in using ICT based on GPA, and the level of TPACK confidence of prospective English teachers, two kinds of questionnaire were used. It was distributed to the 28 prospective English teachers at one of teacher preparation programs at a private universities in Sidoarjo, East Java, Indonesia. Most of the participants were female, and they were in the last year in their study. Related to teaching experience, they have taken micro teaching course as well as Internship III (teaching practice) in various setting and accreditation status of schools. The level of the school students were secondary level, namely, junior high school, senior high school, and vocational high school.

To collect the data, the first step was administering self-report questionnaire about ICT competence. The items were adapted from Jamieson-Proctor, Romina Finger \& Albion (2010). This study asked the subjects' perception about the skill in using sixteen technology applications. To make it easier to understand, each type of application was supported by example as mentioned in Appendix 1.

In addition, first items consisted of several ICT applications that the students were able to use in the teaching process. Then, second items were used to measure the level of general confidence of the participants in using ICT applications during the internship across GPA. Next, the second step was distributing questionnaire whose items were adapted from Bostancioğlu \& Handley (2018) to find out the level of confidence based on TPACK framework. The items are selected by answering these options: very confident - confident - unconfident - very unconfident. Table 1 describes the items in the second questionnaire. 
Items in The Second Questionnaire

\begin{tabular}{|c|l|}
\hline \hline No. & \multicolumn{1}{|c|}{ Items } \\
\hline 1. & $\begin{array}{l}\text { I can teach lessons that appropriately combine English linguistic } \\
\text { concepts, technologies, and teaching approaches }\end{array}$ \\
\hline 2. & $\begin{array}{l}\text { I can select appropriate technologies that combine English culture, } \\
\text { technologies, and teaching approaches }\end{array}$ \\
\hline 3. & $\begin{array}{l}\text { I can select technologies to use in my classroom that enhance what } \\
\text { teach, how I teach, and what students learn }\end{array}$ \\
\hline 4. & $\begin{array}{l}\text { I can use technology effectively to communicate relevant information to } \\
\text { students and peers }\end{array}$ \\
\hline 5. & $\begin{array}{l}\text { I can use a range of technologies to help students pursue their individual } \\
\text { curiosities }\end{array}$ \\
\hline 6. & $\begin{array}{l}\text { I can use a range of technologies that enable students to become active } \\
\text { participants }\end{array}$ \\
\hline 7. & $\begin{array}{l}\text { I can provide equitable access to digital language learning tools and } \\
\text { resource }\end{array}$ \\
\hline 8. & $\begin{array}{l}\text { I can facilitate intercultural understanding by using technology to engage } \\
\text { students with different cultures }\end{array}$ \\
\hline 9. & $\begin{array}{l}\text { I can participate in digital learning communities to explore creative } \\
\text { applications of technology to improve student learning }\end{array}$ \\
\hline
\end{tabular}

To analyze the data in the first step, the researchers compute the number of subjects and descriptively interpret the result of the item 1 response. For the second item as well as the second questionnaire, percentage was used.

\section{FINDINGS AND DISCUSSION}

After analyzing the data obtained from the first questionnaire, the findings reveal that prospective teachers got familiar with many applications, but not for desktop publishing, Database, Web Page development, and Multimedia Development and Composition. Less than 5 prospective teachers select those items. Additionally, the closest applications are presentation software followed by word processing, web browser and web 2.0 and social network as depicted in graphic 2. 
Graphic 2. The ICT Competence of The Prospective Teachers

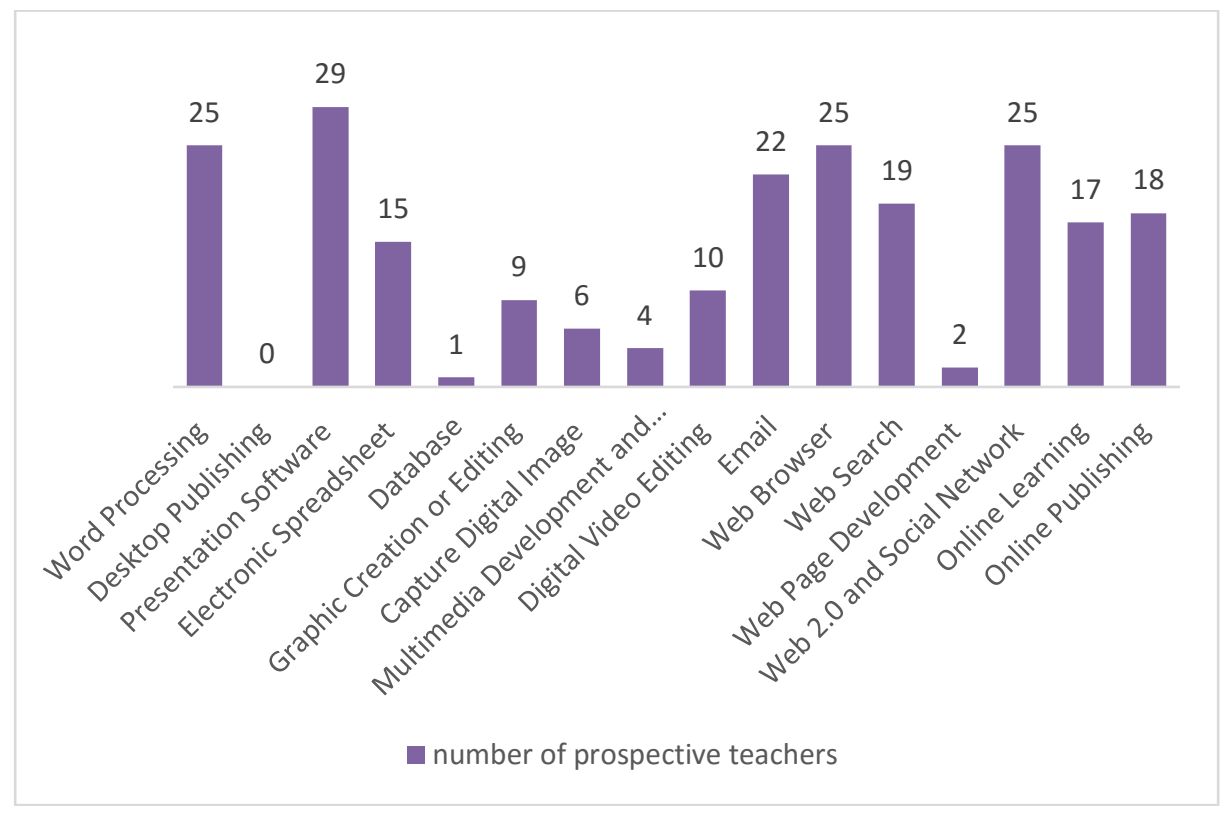

The second question is about ICT confidence. From what was selected in item umber 1, the prospective teachers expressed their general confidence in using the apps variously based on their experience. As described in graphic 2, the prospective teachers are not in the same level of confidence. It is proved based on the dominant perception that they were rather confident in using the application (44\%). Next, $40 \%$ feel confident to use the technology. $13 \%$ of prospective teacher shows their confidence. Finally, as the lowest percentage, 3\% selects unconfident. In general, the results indicates that the familiarity of technology applications is not always supported by the intensive experience in using ICT which affects the users' confidence.

Graphic 3: 
ICT Confidence of Prospective Teachers

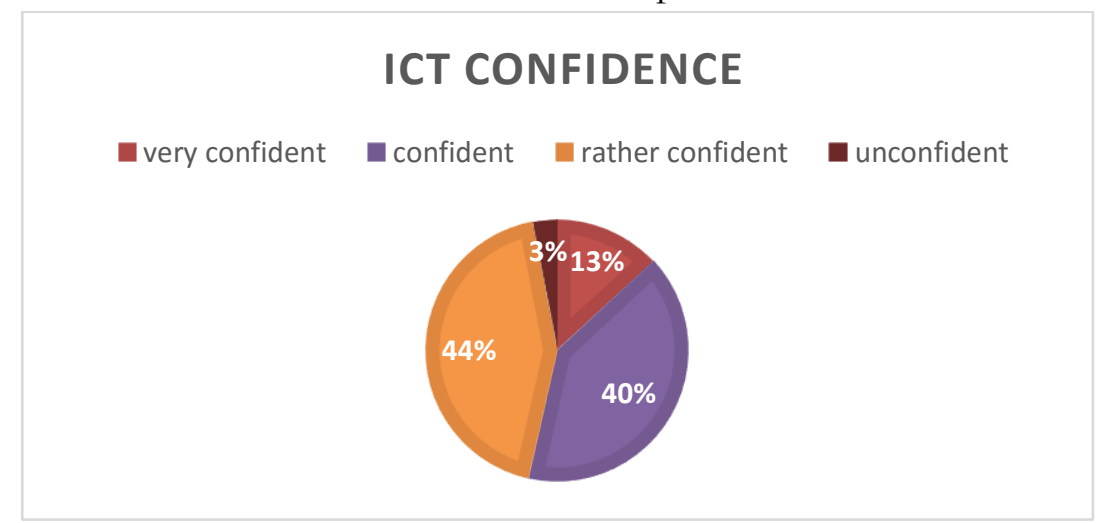

The detailed level of ICT Confidence based on GPA is depicted in Table 2.

Table 2:

The Level of ICT Confidence based on GPA

\begin{tabular}{|c|c|c|c|}
\hline No. & Subject Number & GPA & Level Confidence \\
\hline 1. & Subject Number 1 & 3.21 & Very Confident \\
\hline 2. & Subject Number 2 & 3.91 & Confident \\
\hline 3. & Subject Number 3 & 3.10 & Rather confident \\
\hline 4. & Subject Number 4 & 3.57 & Rather confident \\
\hline 5. & Subject Number 5 & 3.40 & Very Confident \\
\hline 6. & Subject Number 6 & 3.56 & Confident \\
\hline 7. & Subject Number 7 & 3.45 & Confident \\
\hline 8. & Subject Number 8 & 3.44 & Rather confident \\
\hline 9 . & Subject Number 9 & 3.44 & Rather confident \\
\hline 10. & Subject Number 10 & 3.44 & Rather confident \\
\hline 11. & Subject Number 11 & 3.84 & Unconfident \\
\hline 12. & Subject Number 12 & 3.31 & Rather confident \\
\hline 13. & Subject Number 13 & 3.07 & Rather confident \\
\hline
\end{tabular}




\begin{tabular}{|c|c|c|c|}
\hline No. & Subject Number & GPA & Level Confidence \\
\hline 14. & Subject Number 14 & 3.64 & Confident \\
\hline 15. & Subject Number 15 & 3.25 & Confident \\
\hline 16. & Subject Number 16 & 3.70 & Confident \\
\hline 17. & Subject Number 17 & 3.72 & Confident \\
\hline 18. & Subject Number 18 & 3.74 & Rather confident \\
\hline 19. & Subject Number 19 & 3.14 & Confident \\
\hline 20. & Subject Number 20 & 3.80 & Rather confident \\
\hline 21. & Subject Number 21 & 3.75 & Rather confident \\
\hline 22. & Subject Number 22 & 3.39 & Rather confident \\
\hline 23. & Subject Number 23 & 3.58 & Confident \\
\hline 24. & Subject Number 24 & 3.81 & Rather confident \\
\hline 25. & Subject Number 25 & 3.52 & Confident \\
\hline 26. & Subject Number 26 & 3.34 & Very Confidence \\
\hline 27. & Subject Number 27 & 3.58 & Confident \\
\hline 28. & Subject Number 28 & 3.44 & Confident \\
\hline
\end{tabular}

Based on the table 2, it can be seen that the GPA is not always in line with their ICT confidence. The prospective teachers tend to answer confident or rather confident. Surprisingly, one subject selected very confident although the GPA is lower than 3.5., yet one student with GPA 3.84 answered unconfident.

To answer the third research question of this study, perceived confidence to integrate ICT into students learning based on TPACK framework is presented in graphic 4. 
Graphic 4:

EFL Prospective Teachers' TPACK Confidence

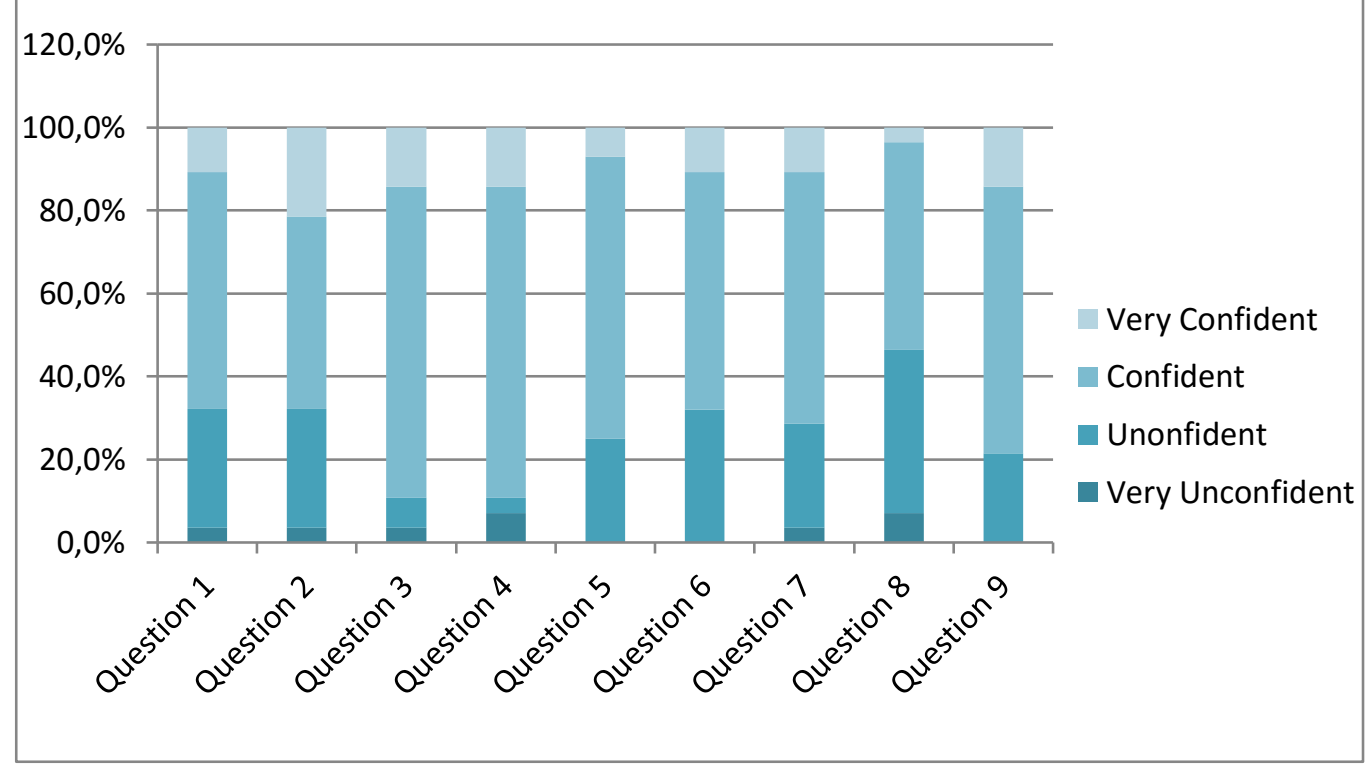

Technological Pedagogical and Content Knowledge survey results indicate that most of the respondents are confident $46.4 \%-75 \%$ out of 28 prospective teachers. However, the percentage of unconfident cannot be ignored since some of the items were selected more than $20 \%$, particularly number $1,2,5,6,7,8$, and 9 .

The following part is discussion which relates the results of the data analysis with theories and relevant previous research to find out the justification or clarification through the obtained evidence of this study.

The first is about ICT competence identified from the kinds of technology used. Among the sixteen applications, presentation software is the most favorable one. PowerPoint is one of effective media for teachers in sharing their materials or presenting related media. It was also experienced in this study. Focusing on the availability of LCD projector and the practicality in sharing materials, media, and tasks, prospective teachers tend to prepare PowerPoint slides for their instruction. Some studies have proved its power to classroom activities more interactive (Clark, 2008; Cosgun Ögeyik, 2017; Meibauer \& Aagaard Nøhr, 2018). To provide joyful activities, PowerPoint can present games for learners (Siko $\&$ Barbour, 2012). For the next emerging application is word processing, web browser, web 2.0 and social network. The three application are the most popular tool for students' learning and assessment. Highlighting social network or social media, it has been something normal to be applied by prospective teachers. Szeto et al., (2016) found that Youtube is the 
common social media was frequently used by digital-native pre-service teachers.

Moreover, the ICT confidence based on GPA in this context gives new insight that affective factor in term of confidence is not always in line with GPA level. Some studies have investigated affective factors but not confidence. Park et al. (2014) have different idea regarding this issue. They agree with the Moreno's Cognitive-Affective Theory of Learning with Media and provide evidence on how affective factor (emotion and interest) can accommodate cognitive processing. Another different result is from Lepp et al. (2015). They found that the use of technology represented by mobile phone is the important predictor of the college students' GPA. The low score was associated with the use of mobile phone.

The result of TPACK confidence in this study indicates that $75 \%$ are confident in the area of technology selection for classroom activities before they use it for the learners and colleagues. This is the highest level among other items in the survey result since the participants selected "confident" to express their perception. Accordingly, a skill to select appropriate technology plays an important role. Some requirements are needed to obtain the effectiveness of the media, i.e. accessibility, performance, practicality, data feedback, efficiency, customizability (Petrick, n.d.).

To respond item number 8 related to intercultural issue, more than $40 \%$ students selected unconfident and very unconfident. This indicates that not all of the prospective teachers had an opportunity to share culture-related lessons to the learners. It is not a big deal in this case since in the teaching practice, they taught based on what was assigned by the mentor, and it was not always about cultures. The common materials that can be shared as the representative of intercultural is stories or narrative. Another form of culture presented in technology is language itself. Through exposing many sources from the Internet, the prospective teachers develop their English language in different situation, formal and informal or academic and non-academic. As a result, what they suggest to the learners during teaching practice was also same. Many online dictionaries very informative in guiding the readers to use the language in appropriate context. Currently, video conferencing (VC) and webinar are getting popular to be used for learning activities. It is not only just receiving materials from the speakers, but also facilitating cultural exchanges (Pim, 2013). 
Interestingly, highlighting the pedagogical concept, not all prospective teachers find themselves confident to teach with technology. Technological knowledge is not sufficient to make them skillful in using the apps for teaching. Both self-improvement and supporting program in teacher education institution are crucial attempt to update the technology use. Related to teacher education program, more sophisticated activities in micro teaching practice may provide prospective teachers a chance to experience various use and kinds of technology which later affect the ICT competence as well as TPACK (Agustin \& Lilisari, 2016).

\section{CONCLUSION}

To sum up, this study provides an evidence that prospective teachers vary their responses in expressing their ICT competence and TPACK confidence. Additionally, GPA seems to contribute to the level of ICT confidence. Further, investigating technology applications used outside classroom and for academic activities needs more deep analysis, particularly on how to use it and why they choose the apps. Dealing with TPACK confidence, prospective teachers are recommended to explore their competence through self-initiated professional development. It is expected that the more exposure the more educational applications they get familiar; as a result, the more confident they integrate technology to English classroom activities. Since this study took small participants, it calls future researchers to carry out deeper analysis on EFL teachers' TPACK confidence with large participants and different method. Combining observation seems to be important to share the process of the implementation.

\section{ACKNOWLEDGMENT}

We gratefully acknowledge the financial support for this study: Universitas Muhammadiyah Sidoarjo through the grant "Riset Terapan Institusi". Next, we thank the reviewers for their insight for the better quality of this article. Finally, we send our appreciation to the participants for their willingness to contribute in this study.

\section{REFERENCES}

Agustin, R. R. R. R., \& Lilisari, L. (2016). Pre-service Science Teachers' Readiness to integrate technology (An Exploration toward TPACK in 
Preliminary Practical Context). Jurnal Pengajaran Matematika Dan Ilmu $\begin{array}{lll}\text { Pengetabuan Alam, 21(2), } & 18269 .\end{array}$ https://doi.org/10.18269/jpmipa.v21i2.830

Al-Abdullatif, A. M. (2019). Auditing the TPACK confidence of pre-service teachers: The case of Saudi Arabia. Education and Information Technologies, 24(6), 3393-3413. https://doi.org/10.1007/s10639-019-09924-0

Batane, T., \& Ngwako, A. (2017). Technology use by pre-service teachers during teaching practice: Are new teachers embracing technology right away in their first teaching experience? Australasian Journal of Educational Technology, 33(1), 48-61. https://doi.org/10.14742/ajet.2299

Bostancioğlu, A., \& Handley, Z. (2018). Developing and validating a questionnaire for evaluating the EFL 'Total PACKage': Technological Pedagogical Content Knowledge (TPACK) for English as a Foreign Language (EFL). Computer Assisted Language Learning, 31(5-6), 572-598. https://doi.org/10.1080/09588221.2017.1422524

Christ, T., Arya, P., \& Liu, Y. (2019). Technology Integration in Literacy Lessons: Challenges and Successes. Literacy Research and Instruction, 58(1), 49-66. https://doi.org/10.1080/19388071.2018.1554732

Clark, J. (2008). Powerpoint and Pedagogy: Maintaining Student Interest in University Lectures. College Teaching, 56(1), 39-44. https://doi.org/10.3200/CTCH.56.1.39-46

Cosgun Ögeyik, M. (2017). The effectiveness of PowerPoint presentation and conventional lecture on pedagogical content knowledge attainment. Innovations in Education and Teaching International, 54(5), 503-510. https://doi.org/10.1080/14703297.2016.1250663

Jamieson-Proctor, Romina Finger, G., \& Albion, P. (2010). Auditing the TK and TPACK confidence of pre-service teachers: are they ready for the profession? Australian Educational Computing, 25(1), 8-17. https://eprints.usq.edu.au/8701/

Kerangka Kerja Kompetensi TIK Guru Menurut UNESCO. (2019). https://www.ybhk.or.id/artikel/kerangka-kerja-kompetensi-tik-gurumenurut-unesco/

Lepp, A., Barkley, J. E., \& Karpinski, A. C. (2014). The relationship between cell phone use, academic performance, anxiety, and Satisfaction with Life in college students. Computers in Human Behavior, 31, 343-350. https://doi.org/10.1016/j.chb.2013.10.049

Lepp, A., Barkley, J., \& Karpinski, A. (2015). The relationship between cell phone use and academic performance in a sample of US college students. Sage Open, 5(1), 1-9. https://doi.org/10.1177/2158244015573169

Meibauer, G., \& Aagaard Nøhr, A. (2018). Teaching Experience: How to Make and Use PowerPoint-Based Interactive Simulations for Undergraduate IR Teaching. Journal of Political Science Education, 14(1), 42-62. https://doi.org/10.1080/15512169.2017.1377083

Mishra, P., \& Koehler, M. J. (2006). Technological pedagogical content 
knowledge: A framework for teacher knowledge. In Teachers College Record (Vol. 108, Issue 6, pp. 1017-1054). Teachers College, Columbia University. https://doi.org/10.1111/j.1467-9620.2006.00684.x

Park, B., Plass, J. L., \& Brünken, R. (2014). Cognitive and affective processes in multimedia learning. Learning and Instruction, 29, 125-127. https://doi.org/10.1016/j.learninstruc.2013.05.005

Petrick, D. (n.d.). 6 Tips for Choosing Educational Technology. Retrieved May 26, 2020, from https://www.wiley.com/network/instructorsstudents/technology-and-innovation/6-tips-for-choosing-educationaltechnology

Pim, C. (2013). Innovations in learning technologies for English language teaching edited by Gary Motteram INNovATIoNS SerIeS. www.britishcouncil.org

Raman, A. (2014). TPACK Confidence of Pre-service Teachers in Universiti Utara Malaysia. Print) Mediterranean Journal of Social Sciences MCSER Publishing, 5(22), 2039-2117. https://doi.org/10.5901/mjss.2014.v5n22p167

Siko, J. P., \& Barbour, M. K. (2012). Homemade PowerPoint Games: Game Design Pedagogy Aligned to the TPACK Framework. Computers in the Schools, 29(4), 339-354. https://doi.org/10.1080/07380569.2012.734430

Szeto, E., Cheng, A. Y. N., \& Hong, J. C. (2016). Learning with Social Media: How do Preservice Teachers Integrate YouTube and Social Media in Teaching? Asia-Pacific Education Researcher, 25(1), 35-44. https://doi.org/10.1007/s40299-015-0230-9

UNESCO. (2011). UNESCO ICT Competency Framework for Teachers UNESCO Biblioteca Digital. https://unesdoc.unesco.org/ark:/48223/pf0000213475

Wang, W., Schmidt-Crawford, D., \& Jin, Y. (2018). Preservice Teachers' TPACK Development: A Review of Literature. Journal of Digital Learning in Teacher Education, 34(4), 234-258. https://doi.org/10.1080/21532974.2018.1498039

Yunita, A., Nursechafia, N., Setiawan, E., \& Nugroho, H. (2018). The Relationship between Mobile Phone Usage in Classroom and Academic Achievement in College Life | Yunita | International Journal of Interactive Mobile Technologies (iJIM). International Journal of Interactive Mobile Technologies (IJIM), 12(8), 96-103. https://onlinejournals.org/index.php/i-jim/article/view/9530/5366

Appendix 1. Item in questionnaire 1

Please select the following ICT applications you are capable of using in your daily and academic activities by giving checklist. You are allowed to choose more than one item.

\begin{tabular}{|l|l|l|l|}
\hline No & Technology Application & Example & Checklist $(\checkmark)$ \\
\hline
\end{tabular}




\begin{tabular}{|l|l|l|l|}
\hline 1 & Word Processing & Microsoft Word & \\
\hline 2 & Desktop Publishing & Microsoft Publisher & \\
\hline 3 & Presentation Software & Microsoft PowerPoint & \\
\hline 4 & Electronic Spreadsheet & Microsoft Excel & \\
\hline 5 & Database & Microsoft Access & \\
\hline 6 & $\begin{array}{l}\text { Graphic Creation or } \\
\text { Editing }\end{array}$ & $\begin{array}{l}\text { Adobe Photoshop, } \\
\text { CorelDraw, Paint, Canva }\end{array}$ & \\
\hline 7 & Capture Digital Image & Digital Cameras, Scanning & \\
\hline 8 & $\begin{array}{l}\text { Multimedia Development } \\
\text { and Composition }\end{array}$ & Flash, Director & \\
\hline 9 & Digital Video Editing & $\begin{array}{l}\text { Adobe Premiere, Movie } \\
\text { Director }\end{array}$ & \\
\hline 10 & Email & $\begin{array}{l}\text { Gmail, Yahoo, Microsoft } \\
\text { Outlook }\end{array}$ & \\
\hline 11 & Web Browser & $\begin{array}{l}\text { Internet Explorer, Google } \\
\text { Chrome, Firefox }\end{array}$ & \\
\hline 12 & Web Search & Google & \\
\hline 13 & Web Page Development & Dreamweaver & \\
\hline 14 & $\begin{array}{l}\text { Web 2.0 and Social } \\
\text { Network }\end{array}$ & $\begin{array}{l}\text { Facebook, Twitter, } \\
\text { YouTube, Whatsapp }\end{array}$ & \\
\hline 15 & Online Learning & Moodle, Edmodo & \\
\hline 16 & Online Publishing & Blog, Podcast, YouTube & \\
\hline
\end{tabular}

